\title{
Isolation and characterization of lactic acid bacteria from fecal pellets, coelomic fluid, and gastrointestinal tract of Nypa worm (Namalycastis rhodochorde) from West Kalimantan, Indonesia
}

\author{
ARI HEPI YANTI ${ }^{1}$, TRI RIMA SETYAWATI ${ }^{1}$, RIKHSAN KURNIATUHADI ${ }^{2, \bullet}$ \\ ${ }^{1}$ Zoology Laboratory, Faculty of Mathematics and Natural Science, Universitas Tanjungpura. Jl. Prof. Dr. H. Hadari Nawawi, Pontianak 78124, West \\ Kalimantan, Indonesia \\ ${ }^{2}$ Microbiology Laboratory, Faculty of Mathematics and Natural Science, Universitas Tanjungpura. J1. Prof. Dr. H. Hadari Nawawi, Pontianak 78124, \\ West Kalimantan, Indonesia. Tel.: +62-561-577963, `email: ari.hepi.yanti@fmipa.untan.ac.id
}

Manuscript received: 17 May 2020. Revision accepted: 23 September 2020.

\begin{abstract}
Yanti AH, Setyawati TR, Kurniatuhadi R. 2020. Isolation and characterization of lactic acid bacteria from fecal pellets, coelomic fluid, and gastrointestinal tract of Nypa worm (Namalycastis rhodochorde) from West Kalimantan, Indonesia. Biodiversitas 21: 4726-4731. Lactic acid bacteria isolated from the intestinal tract as probiotic could be beneficial because they could trigger the growth of the host by enhancing digestibility, increasing their immune system, and inhibiting pathogenic bacteria through the enzymatic process or metabolites production. The purposes of this study were to identify and characterize lactic acid bacteria from fecal pellets, coelomic fluid, and gastrointestinal tract of Nypa worm (Namalycastis rhodochorde). Bacterial isolation was carried out by the pour plate method on de Mann Rogosa Sharp Agar (MRSA). Lactic Acid Bacteria (LAB) isolates were purified and then physiologically characterized by some biochemical tests. Cellulolytic activities were carried out by detecting a clear zone formation on CMC-congo Red Agar. There were 20 isolates of lactic acid bacteria from fecal pellets, coelom fluid, and gastrointestinal tract of nypa worm. Ten isolates (50\%) had cellulolytic activity on CMC-phenol red agar. Eight isolates were closely related to the genus Lactobacillus, while two isolates were closely related to the genus Bacillus. These cellulolytic bacteria could be developed further as probiotic in Nypa worm feed.
\end{abstract}

Keywords: Bacillus, cellulolytic activity, lactic acid bacteria, Lactobacillus, probiotic

\section{INTRODUCTION}

Aquaculture is a global industry that is not only important for the economic sector but also a source of highquality food with potential nutrients from nature (Junardi 2014; Junardi et al. 2019). The use of feed containing Polychaeta for aquaculture has been carried out since it ensures the adequacy of nutrients because it contains several essential fatty acids for the development of the gonads (Costa et al. 2003). Application of Nereis sp. and probiotic in the shrimp feed could improve the biomass and health of the digestive tract of shrimp, thereby reducing the risk of developing viruses, bacteria, and other parasites (Pinon 2000; Costa et al. 2003). Nypa worm (Namalycastis rhodochorde) from Nypa mangrove waters in West Kalimantan, Indonesia, is one of a new species in Polychaeta (Glasby et al. 2007) that has the potential as a feed source for aquaculture. Nypa worms have protein content $>58 \%$ of the biomass (Junardi and Setyawati 2009).

Nypa worm cultivation on laboratory scale has been carried out to prevent over-exploitation of the worm in their natural habitat. The growth of Nypa worms in the laboratory was slower and more susceptible to parasites. It needs 3-4 months to reach 40 segments juvenile (Setyawati et al. 2015). Three components that influence the success of aquaculture are nutrition, digestibility, and disease prevention. According to Wiadnya et al. (2000), physiological aspects of digestion and feed are essential factors for the growth of aquaculture organisms. The slow growth of aquaculture organisms is also influenced by internal conditions, i.e., their low feed digestibility.

The digestibility of Nypa worms can be improved by administering probiotics (living microorganisms in the digestive tract) and prebiotics. A previous study by Yanti et al. (2017) showed that 50 bacteria isolates isolated from fecal pellets, coelomic fluid, gastrointestinal tract have proteolytic activity. Indigenous proteolytic bacteria have great potential to be developed as probiotics for aquaculture feed. Probiotic using indigenous microorganism has a higher probability of competitive exclusion due to adaptation to the same ecological niche (Lalloo et al. 2010). However, the potential of these bacteria must be investigated to determine their potency for improving growth and increasing the biomass of juveniles or adults of Nypa worm. Therefore, it is necessary to determine and select the potential cellulolytic bacteria as an indigenous probiotic in aquaculture, so that these microbes could be safely in feed formula for Nypa worm. The feed product containing probiotics are expected to be safe as energy sources to support the growth of aquaculture organism and a strategy to increase production in aquaculture. 


\section{MATERIALS AND METHODS}

\section{Study area}

Sampling locations of Nypa worms (Namalycastis rhodochorde) were secondary mangrove areas located in the estuary of the Kakap River, Sungai Kakap Village, Kubu Raya District, West Kalimantan, Indonesia. The vegetation of secondary mangrove is dominated by Nypa or nipah trees (Nypa fruticans Wurmb.) as the primary habitat of Nypa worms.

Nypa worms that are collected should meet several conditions, i.e., fifty $\mathrm{cm}$ length, reddish in color, and intact body. Thirty uniform Nypa worms sample were maintained in the laboratory for the bacterial isolation process.

\section{Preparation of growth medium for isolation}

The process of isolation and characterization of lactic acid bacteria was carried out by culturing bacterial isolates on De Man Rogosa and Sharp (MRS) Agar (Meckmillipore). Weight $68.2 \mathrm{~g}$ of MRS agar, and then dissolved in $1 \mathrm{~L}$ of distilled water followed by heating and then sterilizing in an autoclave at $121^{\circ} \mathrm{C}$ for 15 minutes.

\section{Isolation and selection of lactic acid bacteria}

Isolation of lactic acid bacteria (LAB) from fecal pellets, coelom fluids and the gastrointestinal tract of Nypa worms was carried out by pour plate and serial dilution methods. A sterile dissecting set was used to dissect the gastrointestinal tract of the Nypa worm. Ten grams of fecal pellets, coelom fluid, and gastrointestinal tract of Nypa worms were suspended in $90 \mathrm{ml}$ of sterile saline solution and then agitated at a speed of $120 \mathrm{rpm}$ for 30 minutes in a rotary shaker. Serial dilution was carried out by adding 1 $\mathrm{ml}$ of each suspension and mixing it with $9 \mathrm{ml}$ of sterile saline buffer solution to a $10^{-5}$ dilution. One $\mathrm{ml}$ of three suspensions $\left(10^{-3}-10^{-5}\right.$ dilution) were inoculated on MRS agar by pour plate method and incubated for 48 hours at $37^{\circ} \mathrm{C}$.

Morphologically different colony was purified on MRSA media. The purified-culture of each isolate was examined on MRSA using the quadrant streak method. Each purified culture was encoded based on sample type, namely $\mathrm{NrLtF}$ (fecal pellet), NrLtC (coelomic fluid), and $\mathrm{NrLtG}$ (gut). All bacterial isolates were preserved on MRS agar and stored at $4^{\circ} \mathrm{C}$.

\section{Screening of cellulase-produced lactic acid bacteria}

The isolated lactic acid bacteria (LAB) were screened for their cellulolytic activity by determining the clear zone/ halo formed around the bacterial colonies on CMC-congo red agar $\left(\mathrm{CMC} 10 \mathrm{~g} / \mathrm{L} ; \mathrm{MgSO}_{4} .7 \mathrm{H}_{2} \mathrm{O} 0.2 \mathrm{~g} / \mathrm{L} ; \mathrm{KNO}_{3} 0.75\right.$ $\mathrm{g} / \mathrm{L} ; \mathrm{K}_{2} \mathrm{HPO}_{4} 0.5 \mathrm{~g} / \mathrm{L} ; \mathrm{FeSO}_{4} .7 \mathrm{H}_{2} \mathrm{O} 0.02 \mathrm{~g} / \mathrm{L} ; \mathrm{CaCl}_{2} 0.04$ $\mathrm{g} / \mathrm{L}$; yeast extract $2 \mathrm{~g} / \mathrm{L}$; D-glucose $1 \mathrm{~g} / \mathrm{L}$, agar $15 \mathrm{~g} / \mathrm{L}$ ). $\mathrm{LAB}$ cultures were inoculated by swabbing on the agar surface and forming a six mm-circle and then incubated at $37^{\circ} \mathrm{C}$ for 48 hours. After incubation, the formation of a clear zone on CMC-congo red agar indicates that bacteria secrete cellulase enzymes so that they can degrade cellulose. The clear zone and colony diameters were measured using a caliper. The cellulolytic index was calculated using the formula as follows (Ferbiyanto et al. 2015): Cellulolytic index: Diameter of the clear zone Diameter of bacterial colony/ Diameter of bacterial colonies.
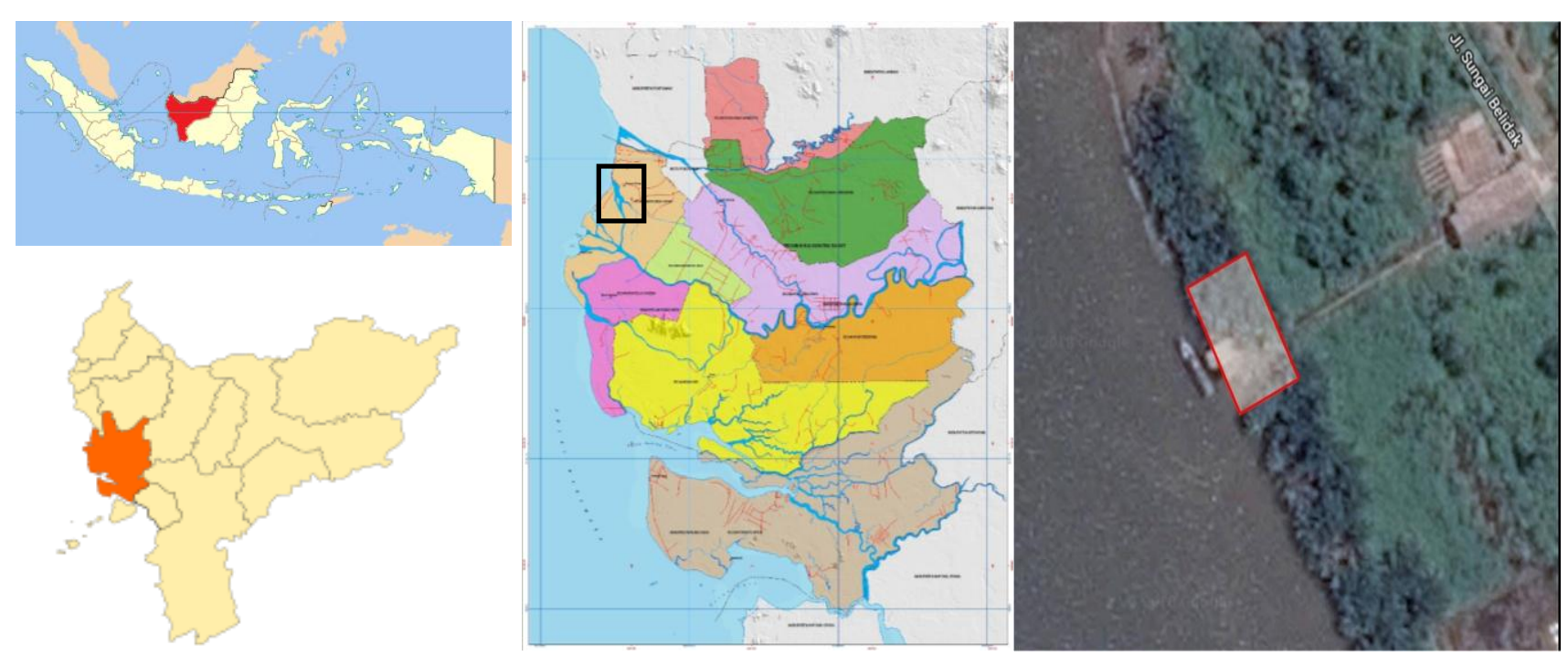

Figure 1. Sampling sites of Nypa worms (Namalycastis rhodochorde)in Sungai Kakap Village, Kubu Raya District, West Kalimantan, Indonesia 


\section{Morphological and biochemical characterization of selected-LAB}

Morphological and biochemical characters of selected lactic acid bacteria were carried out by determining colony characteristics on the MRS agar medium and biochemical characteristics, and the ImVIC test. The observed morphological characters included cell shape by Gram staining, color, edge, and elevation of the colony. Biochemical characters were conducted based on Bergey's guidelines. Several biochemical tests include urease activity, ImVIC test, ornithine decarboxylase test, oxidase test, carbohydrate utilization production gas, and $\mathrm{H}_{2} \mathrm{~S}$, gelatin liquefaction, oxidative fermentative metabolism, and catalase activity.

Determination of optimal pH and temperature for growth

Determination of optimum growth temperature and $\mathrm{pH}$ for growth was carried out by measuring the growth of lactic acid bacteria at various temperatures of $25^{\circ} \mathrm{C}, 30^{\circ} \mathrm{C}$, $35^{\circ} \mathrm{C}$, and $\mathrm{pH}$ values of $5,7,9$ on the MRS broth medium. Bacterial suspensions adjusted to match the turbidity of 0.5 Mcfarland solution were inoculated into $100 \mathrm{ml}$ MRS broth medium and incubated in an incubator shaker for 24 hours. After 24 hours, the turbidity of the bacterial suspensions was measured using a spectrophotometer with a wavelength of $600 \mathrm{~nm}$. Optimum growth occurs in suspensions that have high optical density value.

\section{Identification of selected lactic acid bacteria}

All characteristics of selected lactic acid bacteria were identified based on in Bergeys Determinative of Bacteriology guidelines to determine the genus.

\section{RESULTS AND DISCUSSION}

\section{Isolation and selection of lactic acid bacteria}

The density of lactic acid bacteria from 30 samples of Nypa worms ( $N$. rhodochorde) derived from fresh fecal pellets, coelomic fluid, gastrointestinal tract was presented in Table 1. The number of bacterial colonies isolated from fecal pellets was higher than coelomic fluid and gastrointestinal tract.

Twenty isolates of lactic acid bacteria were successfully purified, i.e., 11 isolates were derived from fecal pellets, six isolates from coelomic fluid, and three isolates from gastrointestinal tract. The selection of purified isolates was based on the different characters of bacterial colonies.

The ability of lactic acid bacterial isolates to break down carbohydrate macromolecules is determined by their ability to break down cellulose. It is indicated by the presence of a clear zone (halo) around the colony (Figure $1)$. There were 10 isolates $(50 \%)$ of lactic acid bacteria that had cellulolytic activity (Figure 1) with varying diameter. NrLtG2 isolate had the largest halo diameter with a high relative index value (2.5) of the bacterial colony on the CMC-Phenol Red Agar Medium. The other bacterial isolates also had a very good index of cellulolytic activity, i.e. > 1(Table 2). Three bacteria isolates (NrLtC2, NrLtC4, and $\mathrm{NrLtG} 2$ ) had a relative index of cellulolytic activity $>2$.
Ten isolates of lactic acid bacteria that have cellulolytic activity are Gram-positive, a chain of rod-shaped bacteria, or leaf-like mesophyll tissue (Figure 2.B). Eight isolates had similar colony characteristics, i.e. spherical, raised to convex, opaque, white, have no pigments (Figure 2.B). Two isolates (NrLtF7 and NrLtF9) had different colony characteristics with irregular colony forms and flat elevations (Figure 2.A).

The results of biochemical tests showed that seven isolates of lactic acid bacteria have weak catalase activity while the $\mathrm{NrLtC} 2$ bacterial isolate has no catalase activity. All isolates were facultatively anaerobic, oxidative and fermentative metabolism, did not produce gas and $\mathrm{H}_{2} \mathrm{~S}$, positive methyl red test, but can not break down gelatin. Several biochemical tests including the citrate test, sucrose, and lactose test, cytochrome oxidase test showed varied (Table 3). All isolates can grow in a temperature range of $28-37^{\circ} \mathrm{C}$, with the optimum temperature for growth is $30^{\circ} \mathrm{C}$.

Based on the results of the morphological characterization of colonies, cells, and physiological characters, we obtained two different groups of bacteria. The first group consisted of eight bacterial isolates, namely NrLtF1, NrLtF2, NrLtF4, NrLtF5, NrLtF8, NrLtC2, NrLtC4, and NrLtG2 with the characters similar to the genus Lactobacillus such as $2-5 \mathrm{~mm}$ colonies on agar media, round and raised or convex colonies, entire, opaque, and without pigment on MRSA, rod-shaped (long rods), Gram-positive, non-sporing, facultative anaerobes, do not break down gelatin, catalase weak positive/negative and cytochrome oxidase negative. The second group consisted of two isolates ( $\mathrm{NrLtF7}$ and $\mathrm{NrLtF}$ ) with the characters similar to the genus Bacillus rod-shaped (long rods), Grampositive, non-sporing, facultative anaerobe, catalase and cytochrome oxidase-positive.

Table 1. The density of lactic acid bacteria isolated from fecal pellets, coelomic fluid, and gut of Nypa worm (Namalycastis rhodochorde)

\begin{tabular}{lll}
\hline Number & Sample & $\begin{array}{l}\text { Number of lactic acid bacteria } \\
(\text { CFU/10 g) }\end{array}$ \\
\hline 1 & Fecal pellets & $2.5 \times 10^{2}$ \\
2 & Coelomic fluid & $1.9 \times 10^{2}$ \\
3 & Gut & $6.1 \times 10^{1}$ \\
\hline
\end{tabular}

Table 2. The values of relative cellulolytic index values of lactic and bacteria isolated from fecal pellets, coelomic fluid, and gut of Nypa worm (Namalycastis rhodochorde)

\begin{tabular}{ll}
\hline Codes of isolates & Cellulolytic index $\left(\mathbf{I}_{\mathbf{c m c}}\right)$ \\
\hline NrLtF 1 & 1.7 \\
NrLtF 2 & 1.3 \\
NrLtF 4 & 1.5 \\
NrLtF 5 & 1.1 \\
NrLtF 7 & 1.7 \\
NrLtF 8 & 1.8 \\
NrLtF 9 & 1.8 \\
NrLtC 2 & 2.4 \\
NrLtC 4 & 2.2 \\
NrLtG 2 & 2.5 \\
\hline
\end{tabular}




\section{Discussion}

The use of probiotics as an alternative to antibiotics has been recommended to be applied in the aquaculture to improve the immune system and optimize the digestibility of several organic macromolecules in aquaculture organisms. Caruffo et al. (2015) recommend the use of indigenous bacteria in the digestive tract be developed as probiotics because they are easier to adapt to the gastrointestinal host conditions so that it would be easy to reach optimal growth. Soccol et al. (2010) stated prolonged interactions of indigenous probiotic bacteria with hosts led to 'balanced relationships' in metabolic activity in both entities. In this study, we isolated microbes from the digestive tract of Nypa worms, and we obtained 58 isolates and 22 fungal isolates from fecal pellets, coelomic fluid, and gastrointestinal tract of Nypa worms. Twenty bacterial isolates were lactic acid bacteria (Yanti et al. 2017: Yanti et al. 2019).

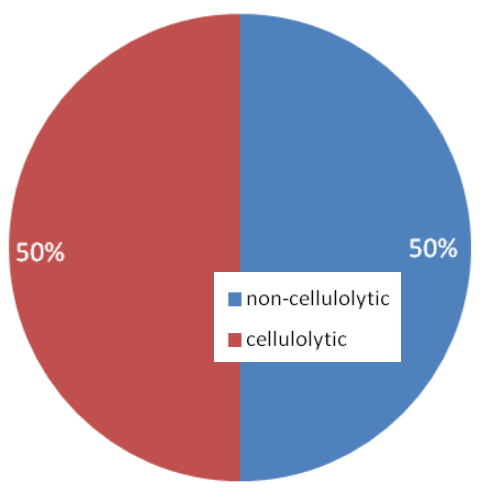

A

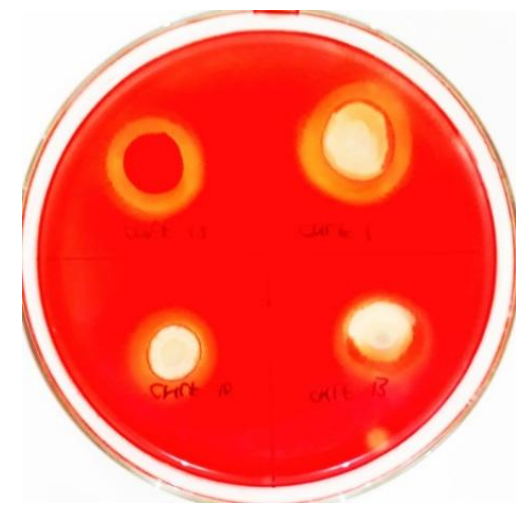

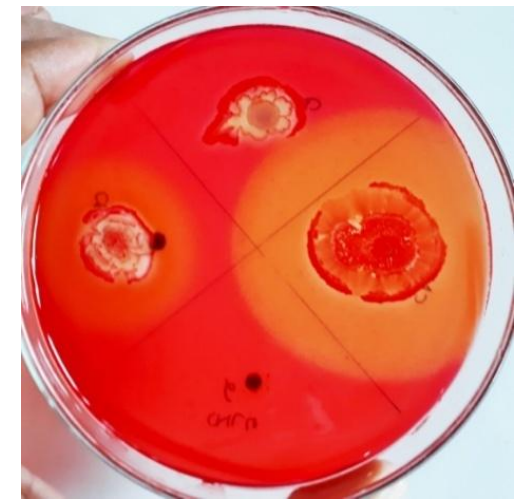

Figure 2. A. Percentage of cellulolytic and non-cellulolytic lactic acid bacteria isolated from Nypa worm (Namalycastis rhodochorde), B. The clear zone/halo formation on CMC Phenol Red Agar indicated cellulolytic activity of lactic acid bacteria

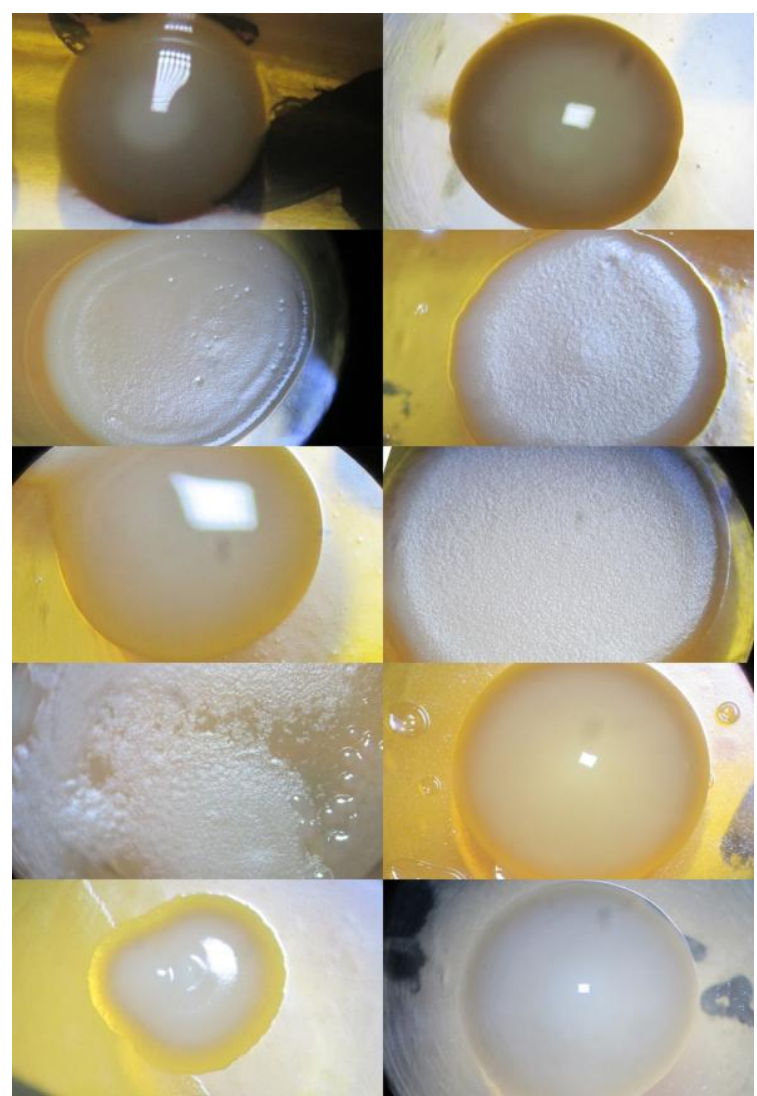

A

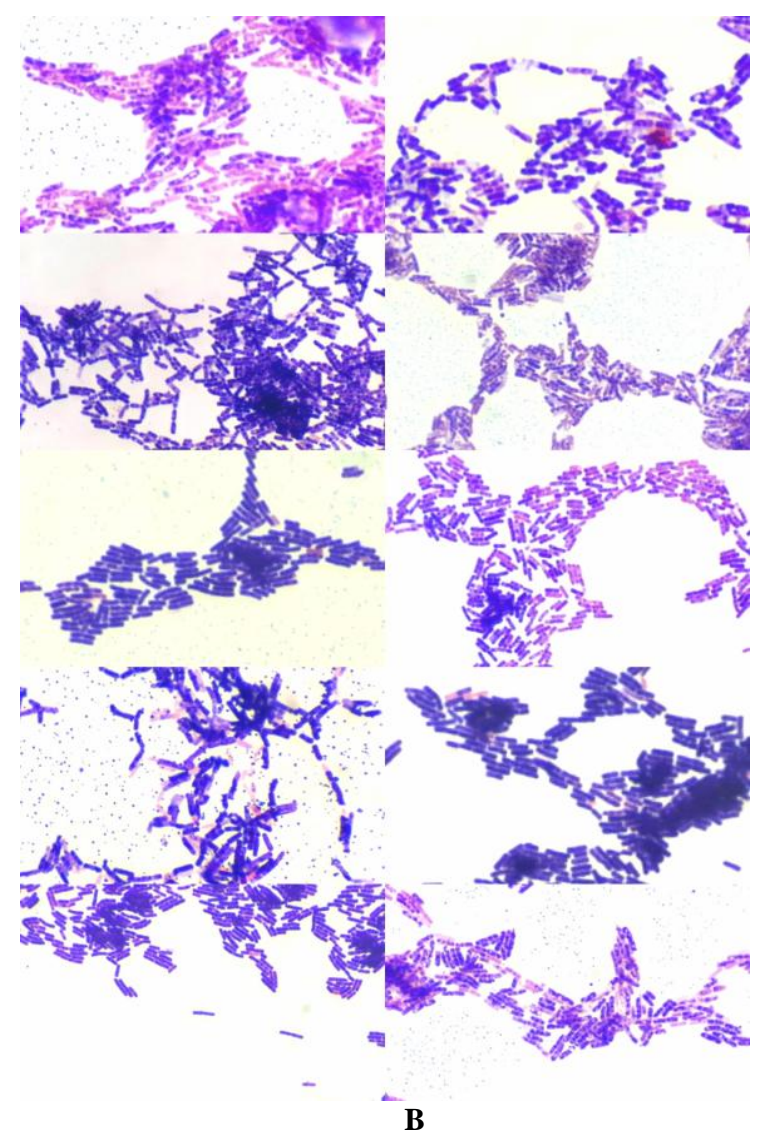

B

Figure 3. Characteristics of the bacterial colony on MRS agar (A); bacterial cell shape and formation (B) of cellulolytic-identified lactic acid bacteria isolated from fecal pellets and gastrointestinal cavity of Nypa worm (Namalycastis rhodochorde) from West Kalimantan, Indonesia 
Table 3. Characteristics of selected lactic acid bacterial isolates from fecal pellets, coelomic fluid, and gastrointestinal tract of Nypa worm (Namalycastis rhodochorde)

\begin{tabular}{|c|c|c|c|c|c|c|c|c|c|c|}
\hline \multirow[t]{2}{*}{ Characters } & \multicolumn{10}{|c|}{ Bacterial codes } \\
\hline & NrLtF1 & NrLtF2 & NrLtF4 & NrLtF5 & NrLtF7 & NrLtF8 & NrLtF9 & NrLtC2 & NrLtC4 & NrLtG2 \\
\hline \multicolumn{11}{|l|}{ Morphological characters: } \\
\hline Cell shape & Bacilli & Bacilli & Bacilli & Bacilli & Bacilli & Bacilli & Bacilli & Bacilli & Bacilli & Bacilli \\
\hline Motility & - & - & - & - & - & - & - & - & - & - \\
\hline Gram & + & + & + & + & + & + & + & + & + & + \\
\hline Endospore & + & - & + & + & - & - & - & - & - & + \\
\hline Cell formation & Chain & Chain & Chain & Chain & Chain & Chain & Chain & Chain & Chain & Chain \\
\hline Form of colony & Round & Round & Round & Round & Iregular & Round & Round & Round & Round & Round \\
\hline Elevation of colony & Raised & Raised & Convex & Convex & Flat & Convex & Raised & Raised & Convex & Convex \\
\hline Color of the colony & White & White & White & White & White & White & White & White & White & White \\
\hline Diameter of colony (mm) & 8 & 4 & 5 & 5 & 20 & 4 & 19 & 5 & 4 & 4 \\
\hline \multicolumn{11}{|l|}{ Biochemical characters: } \\
\hline Catalase & $++^{\mathrm{w}}$ & $+{ }^{\mathrm{w}}$ & $t^{\mathrm{w}}$ & $t^{\mathrm{w}}$ & + & $+^{\mathrm{w}}$ & + & - & $+^{\mathrm{w}}$ & $++^{\mathrm{W}}$ \\
\hline Gelatin liquefaction & - & - & - & - & - & - & - & - & - & - \\
\hline Methyl red test & + & + & + & + & + & + & + & + & + & + \\
\hline Citrate utilization test & - & - & + & + & - & - & - & - & - & - \\
\hline Urease & + & + & + & + & + & + & + & + & + & + \\
\hline Gas production & - & - & - & - & - & - & - & - & - & - \\
\hline $\mathrm{H}_{2} \mathrm{~S}$ production & - & - & - & - & - & - & - & - & - & - \\
\hline Oxidative metabolism & + & + & + & + & + & + & + & + & + & + \\
\hline Fermentative metabolism & + & + & + & + & + & + & + & + & + & + \\
\hline Oxidase reaction & - & - & - & - & + & - & + & - & - & - \\
\hline \multicolumn{11}{|l|}{ Utilization of: } \\
\hline Glucose & + & + & + & + & + & + & + & + & + & + \\
\hline Lactose & - & + & + & - & + & + & + & - & - & + \\
\hline Succrose & - & + & + & - & + & + & + & - & - & + \\
\hline \multicolumn{11}{|c|}{ Optimum ph and temperature } \\
\hline $\mathrm{pH}$ range for growth & $5-7$ & $5-7$ & $5-7$ & $5-7$ & $5-7$ & $5-7$ & $5-7$ & $5-7$ & $5-7$ & $5-7$ \\
\hline Temperature range for grow & $28-37$ & $28-37$ & $28-37$ & $28-37$ & $28-37$ & $28-37$ & $28-37$ & $28-37$ & $28-37$ & $28-37$ \\
\hline Optimal temperature & 30 & 30 & 30 & 30 & 30 & 30 & 30 & 30 & 30 & 30 \\
\hline Genera on Bergey's & $\mathrm{L}$ & $\mathrm{L}$ & $\mathrm{L}$ & $\mathrm{L}$ & B & $\mathrm{L}$ & B & $\mathrm{L}$ & $\mathrm{L}$ & $\mathrm{L}$ \\
\hline
\end{tabular}

Note: + : positive; $+{ }^{\mathrm{w}}$ : weakly positive; - : negative; L: Lactobacillus, B: Bacillus

Previous studies showed that microbes in the gastrointestinal tract of worm consist of fungi, bacteria, actinomycetes, and protozoa (Yanti et al. 2020; Yanti 2019; Kadam and Pathade 2017; Sruthy et al. 2013). Govindarajan (2015) stated that the presence and composition of microbes in the intestinal of worms are due to the availability of mucus and organic compounds derived from natural food and supported by optimum physical-chemical factors in the intestinal tract. Twenty lactic acid bacteria were detected to have cellulolytic properties (Figure 2) so that they can break down the cellulose as the main biomass derived from the litter of Nypa leaves. This activity reflects the association of lactic acid bacteria with the digestive activity of Nypa worm, especially the cellulose substrate as feed. Based on enumeration of lactic acid bacteria from fecal pellets and digestive tracts of Nypa worm, it showed that bacterial concentration ranged from $6.1 \times 10^{1}$ to $2.5 \times 10^{2} \mathrm{CFU} / 10 \mathrm{~g}$ of samples (Table 1.). The number of these bacteria could show an association between lactic acid bacteria and conditions in the digestive tract of Nypa worms. The results showed that the optimum growth of bacteria was $30^{\circ} \mathrm{C}$. This is consistent with the temperature of the study sites.
Lactic acid bacteria in fecal pellets, coelomic fluid, dan gastrointestinal tract of Nypa worms showed the ability to degrade cellulose. The values of the relative cellulolytic index values (Table 2.) indicates a relationship between the type of substrate, feed, and the association of gastrointestinal microbes in Nypa worm. We had profiling cellulolytic activity from twenty isolates isolated from Nypa worms, it indicated $50 \%$ of the lactic acid bacteria isolates producing cellulolytic enzymes. Bacteria isolated in this study were dominated by cellulolytic bacteria (Figure 3). This illustrated the relationship between enzymatic activity and the feed of the Nypa worm that predominantly was Nypa leaf litter mainly composed of cellulose. It stimulates the presence of cellulolytic bacteria in Nypa worm habitat. As a composite feeder, they can enter the gastrointestinal through the ingestion process.

Rowland et al. (2018) stated that intestinal microbiota is the key to describe biochemical profiles of diet or feed, metabolic characteristics, and character of associations with the lack of cellulase-produced hosts. Swetha (2014) stated that the substrate or feed containing cellulose could stimulate the growth of bacteria that can degrade cellulose into cellobiose and glucose disaccharides. A study by Junardi and Setyawati (2009) showed that the living Nypa 
worm (N. rhodochorde) contain high organic carbon that indicated the decomposition process of Nypa litter and accumulated in the Nypa worm habitat or Nypa mangrove sediment. Therefore, cellulolytic bacteria become dominant in the habitat and gastrovascular tract of Nypa worm. Yanti et al. (2017) successfully isolated 32 lactic acid bacteria from Nypa mangrove sediment where Nypa worm lives.

Lactobacillus and Bacillus are the genera of lactic acidproduced bacteria that are most commonly found in various digestive tracts of animals associated with cellulose-rich habitats. Lactobacillus and Bacillus were successfully isolated from the intestinal of giant African snail (Achatina fulica: Gastropods), earthworm (Eudrilus eugeniae: Oligochaeta), and cotton bollworm (Helicoverpa armigera: Insecta) (Mudasir et al. 2017; Shankar et al. 2011: Govindarajan and Prabaharan 2015; Mudasir et al. 2018). The results in this study showed that Lactobacillus is also found in the intestine, coelomic fluid, and fecal pellets of Nypa worm. Gastropods, insects, and worms are known to use the same food sources derived from plants that contain cellulose. Lynd et al. (2002) stated that the symbiotic bacteria from the gut of herbivore are considered to participate in the digestion of cellulose comprising the major part of the plants. In conclusion, twenty isolates lactic acid bacteria had been isolated from fecal pellets, coelomic fluid, and gastrointestinal tract of Nypa worm. Ten isolates showed cellulolytic activity on CMC-phenol red agar. Eight isolates were closely related to the genus Lactobacillus, while two isolates were closely related to the genus Bacillus. Lactobacillus could be developed further as a probiotic for Nypa worm feed.

\section{REFERENCES}

Caruffo M, Navarette N, Salgado O, Diaz A, Paulina L, Garcia K, Celjoo CG, Navarette P. 2015. Potential probiotic yeast isolated from fish gut to protect (Danio rerio) from a Vibrio anguillarium. Front Microbiol 6: 1-9. doi.org/10.3389/fmicb.2015.01093.

Costa PF, Passos AM, da Fonseca LC. 2003. Polychaetes and their potential use in aquaculture. World Aquacult 3 (4): 41-43.

Ferbiyanto A, Rusmana I, Raffiudin R. 2015. Characterization and identification of cellulolytic bacteria from gut of Worker Macrotermes gilvus. HAYATI J Biosci 22 (4): 197-200.

Govindarajan B, Prabaharan V. 2015 Gut bacterial load analysis of earthworms (Eudrillus eugeniae)- A controlled laboratory study. Eur J Environ Ecol 2 (2) https://www.researchgate.net/publication271861544

Glasby CJ, Miura T, Eijiroh, Junardi. 2007. A new species of Namalycastis (Polychaeta: Nereididae) from the shores of Southeast Asia. The Beagle 23: 21-27.

Junardi, Anggraeni T, Ridwan A, Yuwono E. 2014. The maturity of Nypa palm worm (Namalycastis rhodochorde) (Nereididae: Polychaeta). AIP Conference Proceeding 1589 (1): 320-324.

Junardi, Setyawati TR. 2009. Aspek reproduksi dan perkembangan cacing nipah (Namalycastis rodhochorde) (Polychaeta: Nereididae). Laporan Hibah Pekerti II, DIKTI. [Indonesian]
Junardi, Setyawati TR, Mukarlina. 2019. Pembuatan pellet berbahan baku tepung cacing Nypa (Namalycastis rodhochorde) pada petani ikan nila keramba. Jurnal Puruhita 1 (1): 28-31. [Indonesian]

Kadam DG, Pathade GR. 2017. Studies on selected bacteria and glycolytic enzyme activities in the gut of Eudrilus eugeniae. Int $\mathrm{J}$ Curr Microbiol App Sci 6 (4): 2256-2264.

Lalloo R, Moonsamy G, Ramchuran S, Gardiner NS. 2010. Competitive exclusion as a mode of action of a novel Bacillus cereus aquaculture biological agent: competitive exclusion as a mode of action. Lett Appl Microbiol 50 (6): 63-70.

Lynd LR, Weimer PJ, van Zyl WH, Pretorius IS. 2002. Microbial cellulose utilization: Fundamentals and biotechnology. Microbiol Mol Biol Rev 66 (3): 506-577.

Mudasir AD, Afrin AS, Kiran DP, Radhakrisna SP. 2018. Exploring the gut of Helicoverpa armigera for cellulose-degrading bacteria and evaluation of a potential strain for lignocellulosic biomass $\begin{array}{llll}\text { deconstruction. } & \text { Process } & \text { Biochem 73: 143-153. }\end{array}$ https://doi.org/10.1016/j.procbio.2018.08.001.

Mudasir AD, Pawar KD, Pandit RS. 2017. Gut Microbiome Analysis of African Snails: A Biotechnological Approach. INTECH. http//dx.doi.org/10.5772/68133

Pinon E. 2000. Producing ragworm for shrimps broodstock maturation. Global Aquacult Alliance 3: 82-84.

Rowland I, Gibson G, Heinken A, Scott K, Swann J, Thiele I, Tuohy K. 2018. Gut microbiota function: metabolism of nutrients and other food components. Eur J Nutr 57 (1): 1-24. doi: 10.1007/s00394-0171445-8.

Setyawati TR, Junardi, Ari HY. 2015. Paket teknologi budidaya cacing Nypa, Namalycastis rhodocordea (Polychaeta: Nereididae). Laporan Penelitian Hibah Bersaing Tahun II. Universitas Tanjungpura Pontianak. [Indonesian]

Shankar T, Mariappan V, Isaiarasu L. 2011. Screening cellulolytic bacteria from the mid-gut of the popular composting earthworm, Eudrilus eugeniae (Kinberg). World J Zool 6 (2): 142-148.

Soccol CR, Luciana P de Souza, Vandenberghe, Michele RS, Adriane BPM, Caroline TY, Juliano De Dea Lindner, Ashok P, Vanete TS. 2010. The potential of probiotics: A review. Food Technol Biotechnol 48 (4): 413-434.

Sruthy PB, Anjana JC, Rthinamala J, Jayashree R. 2013. Screening of earthworm (Eudrilus eugeniae) gut as a transient microbial habitat. Adv Zool 1 (3): 53-55.

Swetha A. 2014. Cellulases bacterial origin and their application: A Review. Int J Sci Res 358 (10): 1652-1655.

Wiadnya DGR, Hartati Y, Suryanti, Subagyo, Hartadi AM. 2000. Periode pemberian pakan yang mengandung kitin untuk memacu pertumbuhan dan produksi ikan gurami (Osphronemus gouramy Lac.). Jurnal Penelitian Perikanan Indonesia 6 (2): 62-67.

Yanti AH, Setyawati TR, Kurniatuhadi R. 2017. Potential probiotic microflora isolated from coelom fluid, gastrointestinal fluid and fecal pellets of Nypa worm (Namalycastis rhodochorde). Research report on novice educators. Pontianak Tanjungpura University. [Indonesian]

Yanti AH, Setyawati TR, Kurniatuhadi R. 2019. Potential probiotic and antimicrobe agents isolated from Nypa mangrove sediments and fecal pellets of Nypa worm (Namalycastis rhodochorde). Research report on novice educators. Pontianak Tanjungpura University. [Indonesian]

Yanti AH, Setyawati TR, Kurniatuhadi R. 2019. Karakterisasi kapang dari saluran pencernaan cacing nipah (Namalycastis rhodochorde) asal Desa Sungai Kakap, Kabupaten Kubu Raya, Kalimantan Barat. LifeScience 8 (2): 113-125. [Indonesian]

Yanti AH, Setyawati TR, Kurniatuhadi R. 2020. Composition and characterization of actinomycetes isolated from nipah mangrove sediment, gastrointestinal, and fecal pellets of nipah worm (Namalycastis rhodochorde). IOP Conf Ser: Earth Environ Sci 550 (2020) 012016. DOI:10.1088/1755-1315/550/1/012003. 